\title{
Influences of the perceived value on actual repurchasing behavior: Empirical exploration in a retailing context
}

\begin{abstract}
Recent academic studies have reexamined the link between satisfaction and loyalty by introducing actual loyalty behavior. Results of these rare studies are still inconclusive and point out the weakness of the link between satisfaction and behavioral loyalty. This work extends these previous studies by investigating the links between perceived value, satisfaction, attitudinal loyalty and behavorial loyalty. It highlights that perceived value is a better predictor of attitudinal loyalty and behavorial loyalty (number of visits and total sales) than satisfaction. Individual moderating influences are also discussed.
\end{abstract}

\section{Keywords}

Perceived value; satisfaction; attitudinal loyalty; behavioral loyalty; actual repurchasing behavior 


\section{Introduction}

Although marketing professionals regularly highlight the stakes tied to consumers' loyalty, academics continue to question the pertinence and efficacy of existing models of such loyalty (Seiders, Voss, Grewal, \& Godfrey, 2005). These models largely focus on essential elements of the relation between satisfaction and loyalty and mainly study loyalty through attitudinal measures (i.e. behavioral intentions) (Kumar, Dalla Pozza, Petersen, \& Shah, 2009). However, limiting loyalty to behavioral intentions can lead to erroneous conclusions, especially considering the potentially vast differences between intentions and future behavior (Mittal \& Kamakura, 2001; Kamakura, Mittal, De Rosa, \& Mazzon, 2002).

Consequently, several studies point out the necessity to acknowledge how satisfaction can explain observable consumers' behavior (Cooil, Keiningham, Aksoy, \& Hsu, 2007; Vogel, Evanschitzky, \& Ramaseshan, 2008; De Cannière, De Pelsmacker, \& Geuens, 2009; Evanschitzky, Ramaseshan, Woisetschläger, Richelsen, Blut, \& Backhaus, 2012; Nagengast, Evanschitzky, Blut, \& Rudolph, 2014). Such research could offer the capacity to grasp consumers' behavior by combining perceptual measures (satisfaction) with observable measures of loyalty (Gupta \& Zeithaml, 2006).

Researchers also question the status of satisfaction as a predictor of loyalty and encourage managers to examine returns on their investments in programs dedicated to ensuring consumers' satisfaction (Nagengast et al., 2014). Perceived value is a convincing alternative to satisfaction as a predictor of actual loyalty (Kumar, Dalla Pozza, \& Ganesh, 2013). However, in the perceived value-loyalty relationship, loyalty has been still measured through attitudinal indicators (Jones, Reynolds, \& Arnold, 2006; Overby \& Lee, 2006; Lai, Griffin, \& Babin, 2009; Leroi-Werelds, Streukens, Brady, \& Swinnen, 2014).

The current research explores the links between perceived value, satisfaction, attitudinal loyalty and behavorial loyalty. Thereby, it extends the literature pertaining to perceived value as a means to predict actual repurchasing behavior. It also questions existing models that seek to explicate consumers' behavioral loyalty only through satisfaction and attitudinal loyalty.

First, this article pinpoints the interest of integrating actual repurchase behavior to understand consumers' loyalty in complement to attitudinal aspects. It also reviews the studies dedicated to the links between satisfaction and actual loyalty and introduces the concept of perceived value as an explicative variable for actual loyalty. Then, the hypotheses on the links between perceived value, satisfaction, attitudinal loyalty and behavorial loyalty are presented. The methodology used and the results obtained are discussed. Finally, the implications and limitations of the study are noted and future research avenues are proposed.

\section{Conceptual framework}

\subsection{Satisfaction-loyalty behavior: Synthesis and critical perspective}

Defined as an evaluation subsequent to post-consumption affects and cognitions (Oliver, 1999), satisfaction constitutes a fundamental antecedent of the long-term behavior of the customer (Oliver, 1980; Yi, 1990; Cooil et al., 2007). In consequence, the satisfactionloyalty link is a foundation of marketing literature and practice (Anderson \& Mittal, 2000). However, some researchers question this link and suggest the need to go beyond attitudinal 
measures of loyalty, taking actual behavior into account. First, behavioral intentions are not consistent across time and do not translate systematically into actions (De Cannière, De Pelsmacker, \& Geuens, 2009). Second, interpersonal and situational factors make the realization of hoped-for behavior difficult, which may degrade the correlations between behavioral intentions and behavior (Foxall, 2005). Third, simultaneous measures of evaluation judgments (satisfaction) and behavioral intentions may lead to response biases and spurious correlations (Mittal \& Kamakura, 2001).

These elements suggest the need to move away from attitudinal measures of loyalty (e.g. presumed preferences) and to integrate observable measures (revealed preferences), including rates of retention and defection (Bolton, 1998; Capraro, Broniarczyk, \& Srivastava, 2003; Mägi, 2003; Cooil et al., 2007), as well as usage behavior, such as the number of completed transactions or amount spent (Seiders et al., 2005; Evanschitzky et al., 2012). Table 1 summarizes prior studies along these lines.

\section{[Insert Table 1 about here]}

A close examination of the results of these studies suggests the need to question the status of satisfaction as the main predictor of behavioral loyalty (Szymanski \& Henard, 2001; Kumar, Dalla Pozza, \& Ganesh, 2013). Although some studies validate the link between satisfaction and loyalty (Bolton, 1998; Bolton \& Lemon, 1999), the amount of variance in loyalty explained by satisfaction remains weak or even null in other studies (Mägi, 2003; Seiders et al., 2005; Chebat, Davidow, \& Borges, 2011). In addition to the need to investigate the link between satisfaction and loyalty behavior more closely, the nature of this link is not clearly established either; some research implies a linear link (Bolton \& Lemon, 1999), whereas other studies identify a nonlinear or asymmetric link (Mittal \& Kamakura, 2001; Cooil et al., 2007). The satisfaction-loyalty behavior link also appears contextual and dependent on the nature of the relationship between the consumer and the business, especially its (non)contractual nature (Rust, Lemon, \& Zeithaml, 2004; Seiders et al., 2005). The role of satisfaction varies, depending on the nature of the relation between the consumer and the firm (e.g. presence or absence of change costs, discreet or recurrent transactions, embedded or not). Measures of satisfaction also may be insufficient to capture consumers' evaluations accurately (Keiningham, Cooil, Aksoy, Andreassen, \& Weiner, 2007). Accordingly, very elevated levels of satisfaction appear necessary to exert an impact on loyalty behavior. Finally, the transactional and transitory nature of satisfaction suggests that it may be inadequate for understanding loyalty behavior (Mazurski \& Geva, 1989).

These heterogeneous results lead researchers to plead for a theoretical and methodological refinement of the link between satisfaction and loyalty. Voss, Godfrey, and Seiders (2010) call it complex and suggest accounting for the existence of complementary effects or substitutive variables such as satiation or inertia. Keiningham et al. (2007) suggest bypassing single-item measures of satisfaction to enhance their explicative power. Thus, researchers consider some other predictors of loyalty behavior (Kumar, Dalla Pozza, \& Ganesh, 2013), and Oliver (1999) emphasizes that specification problems imply the presence of alternative constructs. In this context, perceived value appears as a convincing potential alternative to satisfaction as a means to explain consumers' loyalty (Parasuraman \& Grewal, 2000; Walsh, Shiu, \& Hassan, 2014). 


\subsection{Perceived value: Antecedent of loyalty and alternative to satisfaction}

Understanding the sources of value of an offer is a key marketing strategy element (Anderson, Narus, \& van Rossum, 2006; Gummerus, 2013). Defining perceived value as "the consumer's overall assessment of the utility of a product based on perceptions of what is received and what is given" (Zeithmal, 1988, p. 14), researchers consider it as a multidimensional concept and seek to identify dimensions associated with value (LeroiWerelds et al., 2014). Starting with the seminal work of Babin, Darden, and Griffin (1994), empirical studies identify aspects of perceived value that are either utilitarian (instrumental values, functional values, efficiency values, excellence values, economic values) or hedonic (recreational values, aesthetics values, playfulness values, experiential stimulation values) in nature (Mathwick, Malhotra, \& Rigdon, 2001; Noble, Griffith, \& Weinberger, 2005; Jones, Reynolds, \& Arnold, 2006; Chai, Malhotra, \& Alpert, 2015).

Beyond conceptualization issues, some studies investigate the role of perceived value in models of consumers' behavior, including the link between perceived value and loyalty. Most of them empirically validate the direct, positive link between perceived value and loyalty. However, most of these studies consider attitudinal measures of loyalty, especially in the form of behavioral intentions (see Table 2). Few studies take into account behavioral loyalty but only through self-declared behavior (Babin \& Attaway, 2000; Sirdeshmukh, Singh, \& Sabol, 2002; Agustin \& Singh, 2005).

\section{[Insert Table 2 about here]}

It is thus necessary to assess with this research the capacity of perceived value to predict actual loyalty behavior. Several arguments suggest considerations of perceived value as a credible alternative to satisfaction to tackle actual loyalty behavior. First, compared with satisfaction, perceived value has a more general measurement range and results from interactions with groups of objects (Boksberger \& Melsen, 2011; Leroi-Werelds et al., 2014). Thus, it offers a sufficiently generalizable theoretical framework to explicate every type of interaction between an individual and an object, regardless of the object or interaction (Holbrook, 1999). Its relational nature also implies a less transitory situation than satisfaction, such that the concept should be pertinent to understanding the problems of loyalty (Agustin \& Singh, 2005; Sanchez Fernandez \& Iniesta-Bonillo, 2007). Perceived value reflects a comparative judgment within and across products (Oliver, 1999). Because it implies considering alternatives that serve as points of reference for consumers' evaluations (Holbrook, 1999), perceived value creates a reasonable analytical framework for comprehending the problems of loyalty in real-world competitive scenarios (Woodruff \& Gardial, 1996). Finally, the richness of the concept has prompted researchers to develop multidimensional measures (Ruiz et al., 2008; Leroi-Werelds et al., 2014), avoiding the pitfall of overly simple measures (Kumar, Dalla Pozza, \& Ganesh, 2013).

\section{Research hypotheses}

The role of perceived value as an antecedent of satisfaction and attitudinal loyalty has been demonstrated (see Table 2). The current research extends this reflection to actual repurchase behavior and postulates the existence of a positive relation between perceived value and actual loyalty behavior. Regardless of the nature of the value, loyalty behavior should emerge following a positive evaluation of utilitarian or hedonic features of the product or service (Babin, Darden, \& Griffin, 1994; Mathwick, Malhotra, \& Rigdon, 2002; Jones, 
Reynolds, \& Arnold, 2006). Further, the current research predicts a stronger positive influence of hedonic value on satisfaction, attitudinal loyalty and actual repurchase behavior, compared with utilitarian value. In effect, consumption contexts capable of generating emotional responses (pleasure, evasion, excitement) lead to stronger forms of evaluation and commitment for the consumer to the company (Dawson, Bloch, \& Rigdway, 1990; Goldsmith \& Goldsmith, 2002; Jones, Reynolds, \& Arnold, 2006; Arnold \& Reynolds, 2012; Scarpi, 2012). Therefore, the affective nature of the hedonic dimensions of perceived value should exert stronger impacts on the subsequent concepts (satisfaction, attitudinal loyalty and actual repurchase behavior) than do the utilitarian dimensions of perceived value. Formally,

$\mathrm{H} 1_{\mathrm{a}, \mathrm{b}, \mathrm{c}}$ Utilitarian value and hedonic value have positive impacts on satisfaction (a), attitudinal loyalty (b) and actual repurchasing behavior (c).

$\mathrm{H} 2_{\mathrm{a}, \mathrm{b}, \mathrm{c}}$ Hedonic value has a stronger impact than utilitarian value on satisfaction (a), attitudinal loyalty (b) and actual repurchasing behavior (c).

In parallel, the role of satisfaction in the formation of loyalty (attitudinal and behavioral) has been posited (see table 1). Thus, this research integrates the relation between satisfaction and loyalty, as established in prior literature. But, perceived value may have a greater impact on loyalty and especially on actual repurchasing behavior than satisfaction. In effect, beyond the weak explicative ability of satisfaction (Kumar, Dalla Pozza, \& Ganesh, 2013), the relational character of value, in contrast with the transactional nature of satisfaction, creates a framework for explaining loyalty (Agustin \& Singh, 2005; Sanchez Fernandez \& Iniesta-Bonillo, 2007). Consequently:

$\mathrm{H}_{\mathrm{a}, \mathrm{b}}$ : Satisfaction has positive impacts on attitudinal loyalty (a) and actual repurchasing behavior (b).

$\mathrm{H} 4 \mathrm{a}, \mathrm{b}$ : Perceived value (utilitarian and hedonic nature) has a stronger impact than satisfaction on attitudinal loyalty (a) and actual repurchasing behavior (b).

Lastly, following prior empirical studies that investigate the role of different constructs as a complementary explanation for observed behavior (Kumar, Pozza and Ganesh, 2013) and taking into account the contingent nature of the relation between perceived value and loyalty (Koller, Floh, \& Zauner, 2011), this research integrates moderating effects. Seiders et al. (2005) identify three categories of potential moderators of the satisfactionloyalty relation: individual characteristics, relational characteristics and market characteristics. Substantial studies confirm the impacts of individual and relational moderators; the effects of market characteristics have not been clearly established (Mittal \& Kamakura, 2001; Gustafsson, Johnson, \& Ross, 2005; Seiders et al., 2005; Kumar, Dalla Pozza, \& Ganesh, 2013), nor sufficiently integrated into extant research. Of the individual moderating influences, gender and motivational orientations exhibit clear effects, including:

- emphases on utilitarian aspects among men but hedonic aspects among women (Noble, Griffith, \& Adjei, 2006; Diep \& Sweeney, 2008; Koller, Floh, \& Zauner, 2011; Arnold \& Reynolds, 2012; Scarpi, 2012).

- the explanatory power of motivational resources with regard to purchasing behavior and the relatively weaker influence of hedonic characteristics associated with evaluation, such that customers mainly rely on functional motives (Kalcheva \& Weitz, 2006; Lunardo \& Mbengue, 2009; Scarpi, 2012).

Among the relational moderating influences (i.e. consumer-company links), the age of the relationship is critical, because previous experience can help to explain value judgments as forms of loyalty (Bolton, 1998; Reinartz \& Kumar, 2003; Verhoef, 2003; Kumar, Dalla Pozza, \& Ganesh, 2013). Overby and Lee (2006) also show that hedonic value is more 
pertinent for explaining consumers' preferences when they lack previous experience with the service. In consequence, this research predicts:

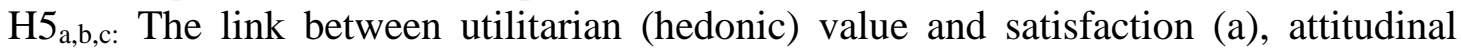
loyalty (b) and actual repurchasing behavior (c) is stronger for men (women).

$\mathrm{H6}_{\mathrm{a}, \mathrm{b}, \mathrm{c:}}$ The link between utilitarian (hedonic) value and satisfaction (a), attitudinal loyalty (b) and actual repurchasing behavior (c) is stronger for consumers with a weak (strong) hedonic orientation.

$\mathrm{H7}_{\mathrm{a}, \mathrm{b}, \mathrm{c}}$ The link between utilitarian (hedonic) value and satisfaction (a), attitudinal loyalty (b) and actual repurchasing behavior (c) is stronger when recent experience with the offering is strong (weak).

\section{[Insert Figure 1 about here]}

Figure 1 reveals the role of perceived value in determining satisfaction, attitudinal loyalty and actual repurchasing behavior ( $\mathrm{H} 1$ and $\mathrm{H} 2)$. By contrast, with the satisfactionloyalty link (H3), this research appreciates the greater impact of perceived value, relative to that of satisfaction (H4). Finally, it presumes the existence of moderators between perceived value and loyalty (H5, H6 and H7).

\section{Method}

\subsection{Study context, sample, and data collection}

To test the research model, the study included first interviews with customers through a questionnaire and then the collection of behavioral information from customers' loyalty cards.

First, during one week, consumers were solicited at the end of their visit in the cultural space of a Hyper $U$ [1], a dedicated space in the immediate proximity of the principal ingress and egress to a hypermarket that features cultural products (e.g. books, cartoons, DVDs, CDs, video games, newspapers). They answered a questionnaire including items on the perceived value associated with their experience at the cultural space studied, their satisfaction and attitudinal loyalty towards this space and its products, their motives to visit the cultural space (i.e. motivational orientations) and their frequency of visits of this space (i.e. relational age). They also answered socio-demographic questions (gender, age, professional activity) and gave us their number on their loyalty card (without mentioning their name and surname to make the questionnaire anonymous).

In this cultural space, the relationship between the company and the consumer is noncontractual (no change costs, discrete transactions), which enhances the potential ability of evaluative judgments to explain actual loyalty (Rust, Lemon, \& Zeithaml, 2004). In addition, issues tied to the commercialization of cultural products (e.g. dematerialization of contents, strong preferences for online purchases) are important to both general and specialized brand names.

Then, a partnership developed with the brand name Système U, enabled the collection of behavioral information from customers' loyalty cards (i.e. numbers of U-card collected). 219 consumers, who provided answers to complete a valid questionnaire as they left the point of sale, were members of the brand name's loyalty program. Système U gathered transactional information about these customers, recorded in the loyalty program. Each time 
consumers visit the store and pay their purchases, the cashier scan their loyalty card and one visit to the cultural space is encoded as well as the amount spent in this space. These behavioral information were collected by Système $U$ for 12 weeks following the survey and were transferred to the authors with the number on the loyalty card indicated for each consumer (wihout mentioning other information such as name and surname). Thanks to the number on the loyalty card, the authors matched the declarative information collected at the end of the visit in the cultural space with the behavioral information transferred by Système U.

Most of the 219 consumers included in this research were women (75.9\%), married or living with someone (80.5\%), 50 years of age or younger $(60.5 \%)$, and employed $(21.8 \%)$ or civil servants (11.4\%).

\subsection{Variables}

Considering the research objectives, this research relied on two categories of variables.

Among the declarative information, the measure of the perceived value associated with experience at the point of sale came from a scale developed by Mathwick, Malhotra, and Rigdon (2001, 2002), which comprises 18 items categorized into four dimensions (aesthetics value, playfulness value, excellence value, economic value). These dimensions parallel the utilitarian and hedonic dimensions of perceived value (Kleijnen, De Ruyter, \& Wetzels, 2007). This scale has strong psychometric qualities, as demonstrated in many studies in retailing contexts (Chen \& Dubinsky, 2003; Wang, Baker, Wagner, \& Wakefield, 2007; Boksberger \& Melsen, 2011). Satisfaction used a three-item measure (Oliver, 1997). Three items measuring behavioral intentions were used to measure attitudinal dimension of loyalty (Zeithaml, Berry \& Parasuraman, 1996). Motivational orientations also relied on three items (Kaltcheva \& Weitz, 2006). Relational age took a single-item measure of a consumer's past visits to the point of sale (Overby \& Lee, 2006).

In terms of the behavioral information, loyalty behavior involved two measures: number of visits to the point of sale and total of achieved sales (Seiders et al., 2005). These indicators are standard proxies for repurchasing behavior in the retailing sector, which lacks any contractual connection with consumers (Reinartz \& Kumar, 2003). Most studies analyzing actual repurchase behavior aggregate sales information over 1-12 months, depending on the study context (Mägi, 2003; Vogel, Evanschitzky, \& Ramaseshan, 2008; Evanschitzky et al., 2012; Nagengast et al., 2014). For the current research, the relatively high purchasing frequency of cultural products provides more observable behavior in a short period (Pan, Sheng, \& Xie, 2012). Therefore, this research aggregated behavioral information about the 219 consumers included in this research over a period of three months.

\section{Results}

Since this research is exploratory and not intended as testing a theoretical model but rather as exploring particular relationships within a model framework we use for outer model and inner model evaluations Partial Least Squares Method (Rönkkö \& Evermann, 2013) by appling a bootstrap method with 500 replications (Tenenhaus, Esposito Vinzi, Chatelin, \& Lauro, 2005). 


\subsection{Outer model evaluation}

The different analyses conducted at this stage indicate the reliability (Jöreskog's, 1971) (Table 3) and convergent validity and discrimimant validity (Table 5) (Fornell and Larcker's, 1981) of the different scales (first- and second-order factors) used in this research: perceived value, satisfaction, and attitudinal loyalty, which were measured using reflexive indicators. Although a few formative outer models of perceived value, satisfaction and attitudinal loyalty exist (Jarvis, MacKenzie, \& Podsakoff, 2003; Ruiz et al., 2008), they are not very widespread. As perceived value is based on a hierarchical construct model - as showed by Mathwick Malhotra, \& Rigdon (2001, 2002) and corroborated by Wetzels, Odekerken-Schröder \& van Oppen (2009) - we used second-order factors which distinguish utilitarian from hedonic value (Table 4). With a higher-order model, a parsimonious inner model can be proposed. The correlations between the first-order factors clearly confirm a higher level of abstraction and the existence of second-order factors (Table 5).

\section{[Insert Table 3 about here]}

\section{[Insert Table 4 about here]}

\section{[Insert Table 5 about here]}

\subsection{Inner model evaluation}

As Table 6 indicates, hedonic values (aesthetics value, playfulness value) have positive effects on satisfaction $(\beta=.460, p<.01)$, attitudinal loyalty $(\beta=.356, p<.01)$, number of visits to the store $(\beta=.229, p<.05)$ and total purchases made $(\beta=.224, p<.05)$. Utilitarian value (excellence value, economic value) have also positive effects on satisfaction $(\beta=.228, p<.01)$, attitudinal loyalty $(\beta=.186, p<.05)$, number of visits to the store $(\beta=$ $.206, p<.05)$ and total purchases made $(\beta=.207, p<.05)$. The comparison of the magnitudes of standardized coefficients shows that hedonic value has a greater impact than utilitarian value on satisfaction, attitudinal loyalty, number of visits to the store and total purchases made. These results support $\mathrm{H} 1$ and $\mathrm{H} 2$.

Satisfaction has a significant impact on attitudinal loyalty $(\beta=.155, p<.05)$ but does not have a significant direct impact on number of visits to the store and total purchases made. Attitudinal loyalty has a significant impact on number of visits to the store $(\beta=.241, p<.01)$ and total purchases made $(\beta=.176, p<.05)$. Thus, the impact of satisfaction on number of visits to the store and total purchases made is only indirect through attitudinal loyalty which is a full mediator of these relationhips. In consequence, H3a is supported contrary to H3b. Considering the magnitudes of standardized coefficients, hedonic value and utilitarian value have a greater impact on attitudinal loyalty compared to satisfaction. In the same vein, hedonic value and utilitarian value have a greater impact on number of visits to the store and total purchases made compared to satisfaction. H4a and H4b are thus validated.

Multigroup analyses provide a test of the impact of the moderating variables. The sample was divided by gender, intensity of the hedonic motivational orientation, and relationship age (Table 7). The permutation tests conducted first indicate the total invariance of the different measurement tools used in this research for the different subgroups formed considering gender, intensity of the hedonic motivational orientation, and relationship age (Chin \& Dibbern, 2010). 


\section{[Insert Table 6 about here]}

As Table 7 indicates, the link between hedonic value and satisfaction is stronger for women than for men $(\Delta \beta=+.351)$ while the link between utilitarian value and satisfaction is stronger for men $(\Delta \beta=+.275)$. In the same vein, the link between hedonic value and attitudinal loyalty is stronger for women than for men $(\Delta \beta=+.258)$ while the link between utilitarian value and attitudinal loyalty is stronger for men $(\Delta \beta=+.191)$. Finally, the link between hedonic value and loyalty behavior is stronger for women than for men (number of visits $\Delta \beta=+.122$, total purchases: $\Delta \beta=+.134$ ). The moderation is reversed for the relation between utilitarian value and actual repurchase behavior, which is stronger for men than for women (number of visits $\Delta \beta=+.147$, total purchases $\Delta \beta=+.129$ ). The results affirm H5.

With regard to motivational orientations, the link between hedonic value and satisfaction is stronger for consumers with a strong hedonic orientation $(\Delta \beta=+.122)$ while the link between utilitarian value and satisfaction is stronger for those with a weak hedonic orientation ( $\Delta \beta=+.139)$. Likewise, the link between hedonic value and attitudinal loyalty is stronger for consumers with a strong hedonic orientation $(\Delta \beta=+.106)$ while the link between utilitarian value and attitudinal loyalty is stronger for those with a weak hedonic orientation ( $\Delta \beta=+.233$ ). Finally, the relation between utilitarian value and actual repurchase behavior is stronger for consumers with a weak hedonic orientation than for those with a strong hedonic orientation (number of visits $\Delta \beta=+.150$, total purchases $\Delta \beta=+.256$ ). A strong hedonic orientation instead amplifies the relation between hedonic value and loyalty behavior (number of visits $\Delta \beta=+.093$, total purchases $\Delta \beta=+.279$ ). H6 is supported by the results.

For the relational moderator (relationship age), the results reveal an unexpected moderation effect. The link between hedonic value and satisfaction is stronger for consumers who exhibit a strong association with the store $(\Delta \beta=+.437)$ while the link between utilitarian value and satisfaction is stronger for those who exhibit a weak association with the store $(\Delta \beta$ $=+.318$ ). Similarly, the link between hedonic value and attitudinal loyalty is stronger for consumers who exhibit a strong association with the store $(\Delta \beta=+.175)$ while the link between utilitarian value and attitudinal loyalty is stronger for those who exhibit a weak association with the store $(\Delta \beta=+.307)$. The link between utilitarian value and real loyalty behavior is stronger for consumers who exhibit a weak association with the store, compared with those with a strong association (number of visits $\Delta \beta=+.214$, total purchases $\Delta \beta=$ +.108 ). A previous strong association with the store instead amplifies the relation between hedonic value and loyalty behavior (number of visits $\Delta \beta=+.180$, total purchases $\Delta \beta=+.230$ ).

These findings conflict with $\mathrm{H} 7$ which posited that the link between utilitarian (hedonic) value and satisfaction, attitudinal loyalty and actual repurchasing behavior is stronger when recent experience with the offering is strong (weak). Therefore, this hypothesis must be rejected. These unexpected results might reflect the nature and format of the point of sale (i.e. specialized space dedicated to cultural products), which is intended to satisfy hedonic needs, whereas discount formats, for example, tend to focus more on satisfying utilitarian and functional needs (Arnold \& Reynolds, 2012).

\section{[Insert Table 7 about here]}




\section{Implications, limitations, and further research}

By exploring the links between perceived value, satisfaction, attitudinal loyalty and behavorial loyalty, this research extends both studies dedicated to the determinants of actual loyalty and those that investigate the role of perceived value in the formation of loyalty.

In the first case, this research specifies the role of perceived value as an antecedent of actual loyalty behavior and a credible alternative to satisfaction (Kumar, Dalla Pozza, \& Ganesh, 2013; Leroi-Werelds et al., 2014). Indeed, perceived value has a high potential to capture fine sources of the evaluative judgments (i.e aesthetics, playfulness, excellence and economic value).

In the second case, though prior studies reveal that perceived value is a determinant of loyalty, they have been limited only to measures of intention (Jones, Reynolds, \& Arnold, 2006; Lai, Griffin, \& Babin, 2009). To fully appreciate the status of perceived value as an explicative variable of loyalty, it was necessary to extend the perceived value-loyalty relationship to real-life loyalty behavior (here, number of visits and total sales). More globally, beyond the empirical results of this research, many arguments point out the benefits of using perceived value to explain real loyalty behavior, especially in terms of its relational nature (Agustin \& Singh, 2005; Sanchez Fernandez \& Iniesta-Bonillo, 2007) and its theoretical richness (Lin, Sher, \& Shih, 2005). In addition, there are limited empirical studies that address moderating influences on actual repurchase behavior (Voss, Godfrey \& Seiders, 2010). This research clearly shows such moderating influence for the perceived value-loyalty behavior relationship.

On a managerial level, this research suggests that managers should deemphasize satisfaction and also place perceived value in their relational marketing programs (Lemon, Rust, \& Zeithaml, 2001; Vogel et al., 2008). The firm's ability to create value for customers could also generate actual loyalty behavior (i.e. number of visits and total purchases). In addition, the importance of hedonic value as a means to explain loyalty behavior emphasizes the necessary but not sufficient characteristics of utilitarian dimensions of an experience at the point of sale (excellence value, economic value) when it comes to developing real customer loyalty. That is, aesthetics value and playfulness value are both efficacious (Dolbec \& Chebat, 2013) and important for the development of true consumers' loyalty. For example, in the book selling industry, retailers such as Chapters (a Canadian bookstore) and Barnes \& Noble (one of the largest retail bookseller in the United States) create both utilitarian and hedonic values in store for consumers to develop real customer loyalty and to face competition with pure players (Amazon, eBay). Utilitarian value is created by rational elements of the store. For example, the convenience of the offer (width and depth of assortment and its clear presentation in the store), the value for money of goods/services, the accuracy of the services and the convenience of the stores could create utilitarian value. In parallel, experiential elements of the store such as its ambiance (music, color, display of products) and design (materials used in the store, different themathic areas created in it) can improve hedonic value. For instance, the stores of Chapters and Barnes \& Noble's both evoke a «cosy lounge " or a «old library room crowded with books » by using specific materials and proposing comfortable reading areas (soft sofas, armchairs, carpets, coffee tables,...) to create hedonic value. For these two retailers, the objective is to increase perceived value associated with the store which in turn could improve consumers' loyalty. Finally, the results regarding the moderators, especially on the individual level, recommend that managers should not assume a homogeneous group of consumers and segment it (Seiders et al., 2005). Although 
for certain consumers, the benefits of their experience in the store strongly explain their actual loyalty behavior, for others, functional benefits remain central determinants of loyalty.

This research contains some limitations. For example, the analysis of the perceived value-loyalty link refers to a particular brand name and sales format. Cultural products constitue also a specific product category which limits the generalization of the results and product category is recognized as a market moderator of the relation between perceptual constructs and behavioral loyalty (Olsen, 2002). The size of our sample (i.e. 219) also limits the generalizability of our results. Consequently, further research should confirm these results by examining the perceived value-loyalty behavior link for other brands, sales formats, product categories (Arnold \& Reynolds, 2012), and on a larger sample of consumers. This research also aggregates sales information over a three-month period, which may be sufficient, considering the frequency of sales in the focal product category (Pan, Sheng, \& Xie, 2012). Yet several studies of loyalty behavior adopt more extended temporal perspectives (Nagengast et al., 2014). Thus, additional research should extend the study period (e.g. to 6-12 months) to affirm the impact of perceived value on loyalty. Still, the measure of the perceptual information took place at time $t$, which implies the stability of these measures in time (Vogel, Evanschitzky, \& Ramaseshan, 2008). Multiplying the measures of perceptual information could lead to more solid inferences about perceived value and actual loyalty behavior. Similarly, the integration of additional moderators-such as product variety, involvement, or temporal pressures (Seiders et al., 2005) — could help refine the contingent nature of the link between perceived value and loyalty behavior. De Matos and Rossi (2008) demonstrate, with a meta-analysis, that a variable such as commitment is a better predictor of recommendation behavior than is satisfaction. Thus, further studies could introduce other alternatives to satisfaction that might explain loyalty behavior and compare them against perceived value as a reflection of consumers' commitment (Verhoef, Franses, \& Hoekstra, 2002), including relationship age (Bolton, 1998), knowledge of alternative offers (Capraro, Broniarczyk, \& Srivastava, 2003) or the level of involvement (Seiders et al., 2005).

\section{Footnotes}

[1] Système $U$ is a cooperative of independent retailers that operate under the brand names Hyper U, Super U, U Express, and Utile and the fourth largest food retailer in France.

\section{References}

Agustin, C., Singh, J., 2005. Curvilinear effects of consumer loyalty determinants in relational exchanges. Journal of Marketing Research 42 (1), 96-108.

Anderson, E.W., Mittal V., 2000. Strengthening the Satisfaction-Profit Chain. Journal of Service Research 3 (2), 107-120.

Anderson, J., Narus, J., van Rossum, W., 2006. Customer value propositions in business markets. Harvard Business Review 84 (3), 91-99.

Arnold, M.J., Reynolds, K.E., 2012. Approach and Avoidance Motivation: Investigating Hedonic Consumption in a Retail Setting. Journal of Retailing 88 (3), 399-411.

Babin, B.J., Darden, W.R., Griffin, M., 1994. Work and/or fun: Measuring hedonic and utilitarian shopping value. Journal of Consumer Research 20 (4), 644-656.

Babin, B.J., Attaway, J.S., 2000. Atmospheric affect as a tool for creating value and gaining share of customer. Journal of Business Research 49 (2), 91-99. 
Boksberger, P.E., Melsen, L., 2011. Perceived value: A critical examination of definitions, concepts and measures for the service industry. Journal of Services Marketing 25 (3), 229-240.

Bolton, R.N., 1998. A dynamic model of the duration of the customer's relationship with a continuous service provider: The role of satisfaction. Marketing Science 17 (1), 45-65.

Bolton, R.N., Lemon, K.N., 1999. A dynamic model of customers' usage of services: Usage as an antecedent and consequence of satisfaction. Journal of Marketing Research 36 (2), 171-186.

Capraro, A.J., Broniarczyk, S., Srivastava, R.K., 2003. Factors influencing the likelihood of customer defection: The role of consumer knowledge. Journal of the Academy of Marketing Science 31 (2), 164-175.

Caruana, A., Ewing, M.T., 2010. How corporate reputation, quality, and value influence online loyalty. Journal of Business Research 63 (9), 1103-1110.

Chai, J.C.Y., Malhotra, N.K., Alpert, F., 2015. A two-dimensional model of trustvalue-loyalty in service relationships. Journal of Retailing and Consumer Services 26, 23-31.

Chebat, J.C., Davidow, M., Borges, A., 2011. More on the role of switching costs in service markets: A research note. Journal of Business Research 64 (8), 823-829.

Chen, C.F., Chen, F.S., 2010. Experience quality, perceived value, satisfaction and behavioral intentions for heritage tourists. Tourism Management 31(1), 29-35.

Chen, Z., Dubinsky, A.J. 2003. A conceptual model of perceived customer value in ecommerce: A preliminary investigation. Psychology \& Marketing 20 (4), 323-347.

Chin, W.W., Dibbern, J., 2010. An introduction to a permutation based procedure for multi-group PLS analysis: results of tests of differences on simulated data and a cross cultural analysis of the sourcing of information system services between Germany and the USA. In: Esposito Vinzi, V., Chin, W.W., Henseler, J. Wang, H. (Ed.), Handbook of Partial Least Squares, Springer Handbooks of Computational Statistics, New York, pp. 171-193.

Cooil, B., Keiningham, T.L., Aksoy, L., Hsu, M., 2007. A longitudinal analysis of customer satisfaction and share of wallet: Investigating the moderating effect of customer characteristics. Journal of Marketing 71 (1), 67-83.

De Cannière, M.H., De Pelsmacker, P., Geuens, M., 2009. Relationship quality and the theory of planned behavior models of behavioral intentions and purchase behavior. Journal of Business Research 62 (1), 82-92.

De Matos, C.A., Rossi, C.A.V., 2008. Word-of-mouth communications in marketing: A meta-analytic review of the antecedents and moderators. Journal of the Academy of Marketing Science 36 (4), 578-596.

Dawson, A., Bloch, P.H., Ridgway, N.M., 1990. Shopping motives, emotional estates, and retail outcomes. Journal of Retailing 66 (4), 408-427.

Diep, V.C.S., Sweeney, J.C., 2008. Shopping trip value: Do stores and products matter?. Journal of Retailing and Consumer Services 15, 399-409.

Dolbec, P.Y., Chebat, J.C., 2013. The impact of a flagship vs. a brand store on brand attitude, brand attachment and brand equity. Journal of Retailing 89(4), 460-466.

Evanschitzky, H., Ramaseshan, B., Woisetschläger, D.M., Richelsen, V., Blut, M., Backhaus, C., 2012. Consequences of customer loyalty to the loyalty program and to the company. Journal of the Academy of Marketing Science 40 (5), 625-638.

Fornell, C., Larcker, D.F., 1981. Evaluating structural equation models with unobservable variables and measurement error. Journal of Marketing Research 18 1, 39-50.

Foxall, G.R., 2005. Understanding consumer choice. Palgrave Macmillan.

Goldsmith, R.E., Goldsmith, E.B., 2002. Buying apparel over the Internet. Journal of Product \& Brand Management 11 (2), 89-102. 
Gruen, T.W., Osmonbekov, T., Czaplewski, A.J., 2006. eWOM: The impact of customer-to-customer online know-how exchange on customer value and loyalty. Journal of Business Research 59 (4), 449-456.

Gummerus, J., 2013. Value creation processes and value outcomes in marketing theory: Strangers or siblings?. Marketing Theory 13 (1), 19-46.

Gupta, S., Zeithaml, V., 2006. Customer metrics and their impact on financial performance. Marketing Science 25 (6), 718-739.

Gustafsson, A., Johnson, M.D., Roos, I., 2005. The effects of customer satisfaction, relationship commitment dimensions, and triggers on customer retention. Journal of Marketing 69 (4), 210-218.

Holbrook, M.B., 1999. Consumer value: A framework for analysis and research. Routledge, London.

Jarvis, C.B., MacKenzie, S.B., Podsakoff, P.M., 2003. A critical review of construct indicators and measurement model misspecification in marketing and consumer research. Journal of Consumer Research 30 (2), 199-218.

Johnson, M.D., Herrmann, A., Huber, F. 2006. The evolution of loyalty intentions. Journal of Marketing 70 (2), 122-132.

Jones, M.A., Reynolds, K.E., Arnold, M.J., 2006. Hedonic and utilitarian shopping value: Investigating differential effects on retail outcomes. Journal of Business Research 59 (9), 974-981.

Jöreskog, K., 1971. Statistical analysis of sets of congeneric tests. Psychometrica 36 (2), 109-133.

Kaltcheva, V.D., Weitz, B.A., 2006. When should a retailer create an exciting store environment?. Journal of Marketing 70 (1), 107-118.

Kamakura, W.A., Mittal, V., De Rosa, F., Mazzon, J.A., 2002. Assessing the serviceprofit chain. Marketing Science 21 (3), 294-317.

Keiningham, T.L., Cooil, B., Aksoy, L., Andreassen, T.W., Weiner, J., 2007. The value of different customer satisfaction and loyalty metrics in predicting customer retention, recommendation, and share-of-wallet. Managing Service Quality: An International Journal 17 (4), 361-384.

Kim, H., Niehm, L.S., 2009. The impact of website quality on information quality, value, and loyalty intentions in apparel retailing. Journal of Interactive Marketing 23 (3), 221233.

Kleijnen, M., De Ruyter, K., Wetzels, M., 2007. An assessment of value creation in mobile service delivery and the moderating role of time consciousness. Journal of Retailing 83 (1), 33-46.

Koller, M., Floh, A., Zauner, A., 2011. Further insights into perceived value and consumer loyalty: A “green” perspective. Psychology \& Marketing 28 (12), 1154-1176.

Kumar, V., Dalla Pozza, I., Ganesh, J., 2013. Revisiting the satisfaction-loyalty relationship: Empirical generalizations and directions for future research. Journal of Retailing 89 (3), 246-262.

Kumar, V., Dalla Pozza, I., Petersen, J.A., Shah, D., 2009. Reversing the logic: The path to profitability through relationship marketing. Journal of Interactive Marketing 23 (2), 147-156.

Lai, F., Griffin, M., Babin, B.J., 2009. How quality, value, image, and satisfaction create loyalty at a Chinese telecom. Journal of Business Research 62 (10), 980-986.

Lemon, K.N., Rust, R.T., Zeithaml, V.A., 2001. What drives customer equity. Marketing Management 10 (1), 20. 
Leroi-Werelds, S., Streukens, S., Brady, M.K., Swinnen, G., 2014. Assessing the value of commonly used methods for measuring customer value: A multi-setting empirical study. Journal of the Academy of Marketing Science 42 (4), 430-451.

Lin, C.H., Sher, P.J., Shih, H.Y., 2005. Past progress and future directions in conceptualizing customer perceived value. International Journal of Service Industry Management 16 (4), 318-336.

Lin, H.H., Wang, Y.S., 2006. An examination of the determinants of customer loyalty in mobile commerce contexts. Information \& management 43 (3), 271-282

Lunardo R., Mbengue A., 2009. Perceived control and shopping behavior: The moderating role of the level of utilitarian motivational orientation. Journal of Retailing and Consumer Services 16 (6), 434-441.

Mägi, A.W., 2003. Share of wallet in retailing: The effects of customer satisfaction, loyalty cards and shopper characteristics. Journal of Retailing 79 (2), 97-106.

Mathwick, C., Malhotra, N., Rigdon, E., 2001. Experiential value: Conceptualization, measurement and application in the catalog and Internet shopping environment. Journal of Retailing, 77 (1), 39-56.

Mathwick, C., Malhotra, N.K., Rigdon, E., 2002. The effect of dynamic retail experiences on experiential perceptions of value: An Internet and catalog comparison. Journal of Retailing 78 (1), 51-60.

Mazursky, D., Geva, A., 1989. Temporal decay in satisfaction-purchase intention relationship, Psychology \& Marketing 6 (3), 211-227.

Mittal, V., Kamakura, W.A., 2001. Satisfaction, repurchase intent, and repurchase behavior: Investigating the moderating effect of customer characteristics. Journal of Marketing Research 38 (1), 131-142.

Nagengast, L., Evanschitzky, H., Blut, M., Rudolph, T., 2014. New insights in the moderating effect of switching costs on the satisfaction-repurchase behavior link. Journal of Retailing 90 (3), 408-427.

Noble, S.M., Griffith, D.A., Adjei, M.T., 2006. Drivers of Local Merchant Loyalty: Understanding the Influence of Gender and Value Orientation. Journal of Retailing 82 (3), 177-188.

Noble, S.M., Griffith, D.A., Weinberger, M.G., 2005. Consumer derived utilitarian value and channel utilization in a multi-channel retail context. Journal of Business Research 58 (12), 1643-1641.

Oliver, R.L., 1980. A cognitive model of the antecedents and consequences of satisfaction decisions. Journal of Marketing Research, 17 (4), 460-469.

Oliver, R.L., 1997. Satisfaction: A behavioral perspective on the consumer. McGrawHill, New-York.

Oliver, R.L., 1999. Value as excellence in the consumption experience. In: Holbrook, M.B. (Ed.), Consumer value: A framework for analysis and research. Routledge, London, pp. 43-61.

Olsen, S.O., 2002. Comparative evaluation and the relationship between quality, satisfaction, and repurchase loyalty. Journal of the Academy of Marketing Science 30 (3), 240-249.

Overby, J.W., Lee, E.J., 2006. The effects of utilitarian and hedonic online shopping value on consumer preference and intentions. Journal of Business Research 59 (10), 11601166.

Pan, Y., Sheng, S., Xie, F., 2012. Antecedents of Customer Loyalty: An Empirical Synthesis and Reexamination. Journal of Retailing \& Consumer Services 19 (1), 150-158. 
Parasuraman, A., Grewal, D., 2000. The impact of technology on the quality-valueloyalty chain: A research agenda. Journal of the Academy of Marketing Science 28 (1), 168174.

Reinartz, W.J., Kumar, V., 2003. The impact of customer relationship characteristics on profitable lifetime duration. Journal of Marketing 67 (1), 77-99.

Rönkko, M., Evermann, J., 2013. A critical examination of common beliefs about partial least squares path modeling. Organizational Research Methods 16 (3), 425-448.

Ruiz, D.M., Gremler, D.D., Washburn, J.H., Carrión, G.C., 2008. Service value revisited: Specifying a higher-order, formative measure. Journal of Business Research, 61 (12), 1278-1291.

Rust, R.T., Lemon, K.N., Zeithaml, V.A., 2004. Return on marketing: Using customer equity to focus marketing strategy. Journal of Marketing, 68 (1), 109-127.

Sanchez-Fernandez, R. Iniesta-Bonillo, M.A., 2007. The concept of perceived value: A systematic review of the research, Marketing Theory 7 (4), 427-451.

Scarpi, D., 2012. Work and fun on the internet: The effects of utilitarianism and hedonism online. Journal of Interactive Marketing 26 (1), 53-67.

Seiders, K., Voss, G.B., Grewal, D., Godfrey, A.L., 2005. Do satisfied customers buy more? Examining moderating influences in a retailing context. Journal of Marketing 69 (4), 26-43.

Sirdeshmukh, D., Singh, J., Sabol, B., 2002. Consumer trust, value, and loyalty in relational exchanges. Journal of Marketing 66 (1), 15-37.

Szymanski, D.M., Henard, D.H., 2001. Customer satisfaction: A meta-analysis of the empirical evidence. Journal of the Academy of Marketing Science 29 (1), 16-35.

Tam, J.L., 2004. Customer satisfaction, service quality and perceived value: an integrative model. Journal of Marketing Management 20 (7-8), 897-917.

Tenenhaus, M., Amato, S., Esposito Vinzi, V., 2004. A global goodness-of-fit index for PLS structural equation modeling. In Proceedings of the XLII SIS Scientific Meeting (pp. 739-742). Padova: CLEUP.

Tenenhaus, M., Esposito Vinzi, V., Chatelin, Y.M., Lauro, C., 2005. PLS path modeling. Computational Statistics Data Analysis 48 (1), 159-205.

Verhoef, P.C., 2003. Understanding the Effect of Customer Relationship Management Efforts on Customer Retention and Customer Share Development. Journal of Marketing 67 (4), 30-45.

Verhoef, P.C., Franses, P.H., Hoekstra, J.C., 2002. The effect of relational constructs on customer referrals and number of services purchased from a multiservice provider: Does age of relationship matter?. Journal of the Academy of Marketing Science 30 (3), 202-216.

Vogel, V., Evanschitzky, H., Ramaseshan, B., 2008. Customer equity drivers and future sales. Journal of Marketing 72 (6), 98-108.

Voss, G.B., Godfrey, A., Seiders, K., 2010. How complementarity and substitution alter the customer satisfaction-repurchase link. Journal of Marketing 74 (6), 111-127.

Walsh, G., Shiu, E., Hassan, L., 2014. Replicating, validating, and reducing the length of the consumer perceived value scale. Journal of Business Research 67 (3), 260-267.

Wang, L.C., Baker, J., Wagner, J.A., Wakefield, K., 2007. Can a retail web site be social?. Journal of Marketing 71 (3), 143-157.

Wetzels, M., Odekerken-Schröder, G., Van Oppen, C., 2009. Using PLS path modeling for assessing hierarchical construct models: Guidelines and empirical illustration. MIS quarterly 33 (1), 177-195.

Woodruff, R.B., Gardial, S.F., 1996. Know your customer: New approaches to tnderstanding customer value and satisfaction. Blackwell Publications, Cambridge, MA. 
Yang, Z., Peterson, R.T., 2004. Customer perceived value, satisfaction, and loyalty: The role of switching costs. Psychology \& Marketing 21 (10), 799-822.

Yi, Y., Hoseong, J., 2003. Effects of loyalty programs on value perception, program loyalty, and brand loyalty. Journal of the Academy of Marketing Science 31 (3), 229-240.

Yoon, Y.S., Lee, J.S., Lee, C.K., 2010. Measuring festival quality and value affecting visitors' satisfaction and loyalty using a structural approach. International Journal of Hospitality Management 29 (2), 335-342.

Zeithaml, V.A., 1988. Consumer perceptions of price, quality, and value: A meansend model and synthesis of evidence. Journal of Marketing 52 (3), 2-22.

Zeithaml, V.A., Berry, L.L., Parasuraman, A., 1996. The behavioral consequences of service quality. Journal of Marketing 60, 31-46. 


\section{TABLES}

Table 1. Empirical studies of the link between consumer satisfaction and real loyalty behavior

\begin{tabular}{|c|c|c|c|}
\hline Source & Measure of actual loyalty behavior & $\begin{array}{l}\text { Nature of the consumer-firm } \\
\text { relation }\end{array}$ & Key results \\
\hline Bolton (1998) & $\begin{array}{l}\text { Length of consumer relations with } \\
\text { the business }\end{array}$ & Contractual (cell phone) & $\begin{array}{l}\text { 1. Satisfaction influences the length of the relationship. } \\
\text { 2. This link varies with certain relational characteristics (e.g. previous experience with the } \\
\text { business, role of service encounters). }\end{array}$ \\
\hline $\begin{array}{l}\text { Bolton and Lemon } \\
\text { (1999) }\end{array}$ & $\begin{array}{l}\text { Consumption quantity (number of } \\
\text { minutes each month) for a 3-month } \\
\text { period }\end{array}$ & $\begin{array}{l}\text { Contractual (pay television and } \\
\text { cell phones) }\end{array}$ & $\begin{array}{l}\text { 1. Consumers' global satisfaction affects the usage behavior of consumers. } \\
\text { 2. The results are homogeneous in the two contexts studied. }\end{array}$ \\
\hline $\begin{array}{l}\text { Mittal and } \\
\text { Kamakura (2001) }\end{array}$ & Repurchase of the same brand & $\begin{array}{l}\text { Contractual (automobile } \\
\text { industry) }\end{array}$ & $\begin{array}{l}\text { 1. If a link exists between satisfaction and repurchases, it is nonlinear and depends on } \\
\text { consumers' characteristics. } \\
\text { 2. For some consumers, the level of satisfaction does not correlate with repurchase behavior. }\end{array}$ \\
\hline $\begin{array}{l}\text { Verhoef, Franses } \\
\text { and Hoekstra (2002) }\end{array}$ & $\begin{array}{l}\text { Number of services purchased by } \\
\text { clients }\end{array}$ & $\begin{array}{l}\text { Contractual (insurance } \\
\text { companies) }\end{array}$ & $\begin{array}{l}\text { 1. Satisfaction does not affect the number of services purchased. } \\
\text { 2. Affective engagement, equity associated with payment, and relational age have significant } \\
\text { effects on the number of services purchased. }\end{array}$ \\
\hline $\begin{array}{l}\text { Capraro, } \\
\text { Broniarczyk and } \\
\text { Srivastava (2003) }\end{array}$ & Rate of defection & Contractual (health insurance) & $\begin{array}{l}\text { 1. Satisfaction explains the probability of consumer defection. } \\
\text { 2. Consumer knowledge about alternative offers explains more than twice as much variance } \\
\text { associated with the probability of defection. }\end{array}$ \\
\hline Mägi (2003) & $\begin{array}{l}\text { Rate of retention (purchases and } \\
\text { visits) of consumers in the main } \\
\text { store during a 4-week period }\end{array}$ & $\begin{array}{l}\text { Non-contractual (points of sale, } \\
\text { foodstuffs) }\end{array}$ & $\begin{array}{l}\text { 1. Client satisfaction has a positive effect on the rate of retention, but the variance in the rate of } \\
\text { retention explained by satisfaction is weak. } \\
\text { 2. The relation between client satisfaction and rate of retention is moderated by customers' } \\
\text { economic orientation. }\end{array}$ \\
\hline Seiders et al. (2005) & $\begin{array}{l}\text { Number of visits to the point of } \\
\text { sale and amount spent during a } 52- \\
\text { week period following the inquiry }\end{array}$ & $\begin{array}{l}\text { Non-contractual (retailer } \\
\text { specialized in luxury clothes and } \\
\text { furniture) }\end{array}$ & $\begin{array}{l}\text { 1. Satisfaction has a strong influence on repurchase intentions but does not have a direct effect } \\
\text { on repurchase behaviors. } \\
\text { 2. Individual consumer characteristics, relational characteristics, and market characteristics } \\
\text { moderate the relation between satisfaction and repurchase behavior. }\end{array}$ \\
\hline Cooil et al. (2007) & $\begin{array}{l}\text { Rate of client retention over a } 5 \text { - } \\
\text { year period years }\end{array}$ & Contractual (banking institutions) & $\begin{array}{l}\text { 1.A positive and non-linear relation exists between changes in the level of satisfaction and } \\
\text { changes to the rate of retention. } \\
\text { 2. The link is weakly significant for several consumer groups (a function of individual } \\
\text { consumer characteristics, such as the initial level of satisfaction or income level). }\end{array}$ \\
\hline $\begin{array}{l}\text { De Cannière, De } \\
\text { Pelsmacker and } \\
\text { Geuens (2009) }\end{array}$ & $\begin{array}{l}\text { Number of visits to the point of } \\
\text { sale, amount spent, and products } \\
\text { purchased by the consumer over a } \\
\text { 6-month period }\end{array}$ & $\begin{array}{l}\text { Non-contractual (retailer } \\
\text { specialized in clothes) }\end{array}$ & $\begin{array}{l}\text { 1. Satisfaction (integrated with a relational construct that includes both confidence and } \\
\text { engagement) has a positive impact on repurchase behaviors. } \\
\text { 2. Concepts associated with a model of planned behavior (attitude, perceived and subjective } \\
\text { control) have significantly higher impacts than satisfaction on these behaviors. }\end{array}$ \\
\hline $\begin{array}{l}\text { Chebat, Davidow } \\
\text { and Borges (2011) }\end{array}$ & Rate of defection & Contractual (banking institution) & $\begin{array}{l}\text { 1. Satisfaction following complaint handling explains client defection. } \\
\text { 2. Certain change costs moderate the satisfaction-defection relation. }\end{array}$ \\
\hline Evanschitzky et al. & Actual consumer spending in the 6 & Non-contractual (grocery & 1. Satisfaction exerts a positive influence on loyalty to the business (attitudinal measure), which \\
\hline
\end{tabular}




\begin{tabular}{|l|l|l|l|}
\hline$(2012)$ & months following the inquiry & retailer) & $\begin{array}{l}\text { itself is an antecedent of actual spending. } \\
\text { 2. Trust and commitment are better predictors of loyalty toward the business, and attitude } \\
\text { toward a loyalty program is a better predictor of actual spending. }\end{array}$ \\
\hline $\begin{array}{l}\text { Nagengast et al. } \\
(2014)\end{array}$ & $\begin{array}{l}\text { Consumer spending in the year } \\
\text { following the inquiry }\end{array}$ & $\begin{array}{l}\text { Non-contractual (grocery } \\
\text { retailer) }\end{array}$ & $\begin{array}{l}\text { 1. Satisfaction has a positive effect on repurchase behavior. } \\
\text { 2. Change costs exert a moderating, non-linear effect (inverse U-shaped curve) on the } \\
\text { satisfaction-loyalty relation. }\end{array}$ \\
\hline
\end{tabular}


Table 2. Empirical studies exploring the link between consumer perceived value and attitudinal loyalty

\begin{tabular}{|c|c|c|}
\hline Source & Loyalty measure & Key results \\
\hline $\begin{array}{l}\text { Babin and Attaway } \\
(2000)\end{array}$ & $\begin{array}{l}\text { Share of customer (self-declared } \\
\text { behavior) }\end{array}$ & $\begin{array}{l}\text { 1. Utilitarian and hedonic values are positively related to customer share. } \\
\text { 2. Perceived value mediates the relationship between affect and customer share. }\end{array}$ \\
\hline $\begin{array}{l}\text { Sirdeshmukh, Singh, } \\
\text { and Sabol (2002) }\end{array}$ & $\begin{array}{l}\text { Intentions to recommend, probability } \\
\text { of repeated purchases, portion of } \\
\text { purchases in the category (self- } \\
\text { declared behavior) }\end{array}$ & $\begin{array}{l}\text { 1. Perceived value positively influences loyalty. } \\
\text { 2. Perceived value partially mediates the relation between trust and loyalty. }\end{array}$ \\
\hline $\begin{array}{l}\text { Yi and Hoseong } \\
(2003)\end{array}$ & $\begin{array}{l}\text { Attitude to the loyalty program } \\
\text { (program loyalty), attitude to the } \\
\text { brand (brand loyalty) }\end{array}$ & $\begin{array}{l}\text { 1. Perceived value (associated with a loyalty program) positively influences loyalty to the brand. } \\
\text { 2. Loyalty to a loyalty program is a partial mediator of the perceived value-brand loyalty relation. } \\
\text { 3. The relations are not homogeneous for all consumers but depend on consumers' involvement with the product category. }\end{array}$ \\
\hline Tam (2004) & $\begin{array}{l}\text { Behavioral intentions (future } \\
\text { repurchases and recommendation } \\
\text { intentions) }\end{array}$ & $\begin{array}{l}\text { 1. Perceived value has a positive effect on post-purchase behaviour. } \\
\text { 2. Perceived value has an indirect positive effect on post-purchase behavior via customer satisfaction. }\end{array}$ \\
\hline $\begin{array}{l}\text { Yang and Peterson } \\
\text { (2004) }\end{array}$ & $\begin{array}{l}\text { Behavioral intentions (purchases and } \\
\text { recommendations) }\end{array}$ & $\begin{array}{l}\text { 1. Perceived value positively affects client loyalty to the business. } \\
\text { 2. Satisfaction mediates the perceived value-loyalty relation; change costs moderate the perceived value-loyal }\end{array}$ \\
\hline $\begin{array}{l}\text { Agustin and Singh } \\
\text { (2005) }\end{array}$ & $\begin{array}{l}\text { Probability of a repeat purchase and } \\
\text { portion of future purchases with the } \\
\text { supplier (self-declared behavior) }\end{array}$ & $\begin{array}{l}\text { 1. A curvilinear relation exists (linear and quadratic effects) between perceived value and loyalty to the business. } \\
\text { 2. Perceived value has a partial mediating role in the relation between satisfaction and loyalty to the business. }\end{array}$ \\
\hline $\begin{array}{l}\text { Gruen, Osmonbekov } \\
\text { and Czaplewski (2006) }\end{array}$ & $\begin{array}{l}\text { Behavioral intentions (purchases and } \\
\text { recommendations) }\end{array}$ & $\begin{array}{l}\text { 1. Perceived produc } \\
\text { 2. Perceived value } \mathrm{p}\end{array}$ \\
\hline $\begin{array}{l}\text { Johnson, Herrmann } \\
\text { and Huber (2006) }\end{array}$ & Behavioral intentions & $\begin{array}{l}\text { 1. Perceived value exerts a positive effect on loyalty, but this influence declines over time. } \\
\text { 2. Affective engagement and major brands mediate the perceived value-loyalty relation. }\end{array}$ \\
\hline $\begin{array}{l}\text { Jones, Reynolds and } \\
\text { Arnold (2006) }\end{array}$ & $\begin{array}{l}\text { Intentions to return, intentions to } \\
\text { recommend, attitudinal loyalty }\end{array}$ & $\begin{array}{l}\text { 1. Types of perceived value (hedonic/utilitarian) associated with the store exerts a positive effect, differentiated by the } \\
\text { different indicators of loyalty to the store. } \\
\text { 2. Perceived value of shopping moderates the relation between satisfaction and different indicators of loyalty. }\end{array}$ \\
\hline Lin and Wang (2006) & $\begin{array}{l}\text { Attitudinal commitment and } \\
\text { behavioral repurchase intentions }\end{array}$ & $\begin{array}{l}\text { 1. Perceived value has a positive effect on customer loyalty. } \\
\text { 2. If satisfaction exhibited the strongest direct effect on customer loyalty, perceived value exhibited a stronger total (direct } \\
\text { and indirect) effect on customer loyalty. }\end{array}$ \\
\hline Overby and Lee (2006) & $\begin{array}{l}\text { Attitudes (preference), intention to } \\
\text { return }\end{array}$ & $\begin{array}{l}\text { 1. Value judgments (hedonic/utilitarian) associated with online stores have positive, direct influences that vary with the } \\
\text { preferences of the consumers, who in turn have direct and positive influences on intentions to return to the website. } \\
\text { 2. The perceived value-loyalty relation is moderated by the last experience the consumer had with the business. }\end{array}$ \\
\hline $\begin{array}{l}\text { Ruiz, Gremler, } \\
\text { Washburn, \& Carrión } \\
(2008)\end{array}$ & Repurchase intentions & 1. A linear and positive relation exists between the perceived value of the service and repurchase intentions. \\
\hline Lai, Griffin and Babin & Behavioral intentions (purchases and & 1. Perceived value of the service has a positive effect on loyalty to the business. \\
\hline
\end{tabular}




\begin{tabular}{|c|c|c|}
\hline (2009) & recommendation) & 2. Among the antecedents (quality, image, and satisfaction), perceived value exerts the strongest impact on loyalty. \\
\hline Kim and Niehm (2009) & Behavioral intentions & $\begin{array}{l}\text { 1. Perceived value (of the website) positively influences client loyalty to the site. } \\
\text { 2. Perceived value (of the website) exerts a mediating effect on the relation between perceived quality of information and } \\
\text { client loyalty to the website. }\end{array}$ \\
\hline Chen and Chen (2010) & Behavioral intentions & 1. The higher the value that heritage tourists perceive, the more positive the behavioral intentions they have. \\
\hline $\begin{array}{l}\text { Caruna and Ewing } \\
(2010)\end{array}$ & Behavioral intentions & $\begin{array}{l}\text { 1. Perceived value (of the website) has a direct, positive impact on consumers' online loyalty. } \\
\text { 2. The reputation of the business partially mediates the perceived value-loyalty relation. }\end{array}$ \\
\hline $\begin{array}{l}\text { Yoon, Lee and Lee } \\
(2010)\end{array}$ & Behavioral intentions & 1. Perceived value of festival indirectly enhanced loyalty through satisfaction. \\
\hline $\begin{array}{l}\text { Koller, Floh and } \\
\text { Zauner (2011) }\end{array}$ & $\begin{array}{l}\text { Intentions to repurchase and } \\
\text { recommend }\end{array}$ & $\begin{array}{l}\text { 1. Functional, social, and emotional dimensions of perceived value have direct and positive effects on consumer loyalty to } \\
\text { the brand. The functional dimension of perceived value has the strongest impact on consumers' loyalty to the brand. } \\
\text { 2. The economic dimension of perceived value does not affect loyalty to the brand. } \\
\text { 3. The functional, social, and emotional dimensions of perceived value exert totally mediating effects in the relation } \\
\text { between the ecological dimension of perceived value and loyalty to the brand. }\end{array}$ \\
\hline $\begin{array}{l}\text { Leroi-Werelds et al. } \\
\text { (2014) }\end{array}$ & $\begin{array}{l}\text { Intentions to repurchase and } \\
\text { recommend }\end{array}$ & $\begin{array}{l}\text { 1. There is a positive relation between perceived value and loyalty. } \\
\text { 2. This relation is validated with different measures of perceived value and for different categories of products. }\end{array}$ \\
\hline $\begin{array}{l}\text { Chai, Malhotra and } \\
\text { Alpert (2015) }\end{array}$ & $\begin{array}{l}\text { Intentions to repurchase and } \\
\text { recommend }\end{array}$ & $\begin{array}{l}\text { 1. Utilitarian value has a direct and positive impact on repurchasing intentions. } \\
\text { 2. Hedonic value has a direct and positive impact on recommendation intentions. }\end{array}$ \\
\hline
\end{tabular}


Table 3. Outer model evaluation

\begin{tabular}{|c|c|c|c|c|c|}
\hline \multirow[b]{2}{*}{$\begin{array}{l}\text { First-order } \\
\text { factors }\end{array}$} & \multirow[b]{2}{*}{ Items } & \multirow[b]{2}{*}{ Loadings } & \multirow[b]{2}{*}{$t$} & \multicolumn{2}{|c|}{ Composite reliability } \\
\hline & & & & $\begin{array}{l}\text { First-order } \\
\text { factors }\end{array}$ & $\begin{array}{l}\text { Second- } \\
\text { order } \\
\text { factors }\end{array}$ \\
\hline \multirow{6}{*}{$\begin{array}{l}\text { Aesthetics } \\
\text { value }\end{array}$} & The manner in which this space presents its products is attractive. & .843 & $16.197^{*}$ & \multirow{6}{*}{.930} & \multirow{11}{*}{$\begin{array}{c}\text { Hedonic } \\
\text { value, } \\
.944\end{array}$} \\
\hline & I find this space entertaining. & .814 & $12.868 *$ & & \\
\hline & I like the look of this space very much. & .830 & $14.442 *$ & & \\
\hline & This space is nice to look at. & .851 & $12.486^{*}$ & & \\
\hline & This space does not just sell products; it is also an entertaining spot. & .856 & 11.863* & & \\
\hline & The good ambiance present in this space is contagious. & .783 & $11.602 *$ & & \\
\hline \multirow{5}{*}{$\begin{array}{l}\text { Playfulness } \\
\text { value }\end{array}$} & $\begin{array}{l}\text { When I am in this space, I am so engrossed in my visit that I don't } \\
\text { think of anything else. }\end{array}$ & .869 & $17.500^{*}$ & \multirow{5}{*}{.925} & \\
\hline & $\begin{array}{l}\text { I love coming to this space, not just for the products I can buy here, } \\
\text { but also to enjoy the space. }\end{array}$ & .882 & $17.905 *$ & & \\
\hline & When I'm in this space, I have the feeling of being in another world. & .882 & $17.963 *$ & & \\
\hline & When I'm in this space, I forget all the rest. & .789 & $14.805^{*}$ & & \\
\hline & I come to this space for pure pleasure. & .782 & $13.760^{*}$ & & \\
\hline \multirow{2}{*}{$\begin{array}{l}\text { Excellence } \\
\text { value }\end{array}$} & $\begin{array}{l}\text { I find that this space is truly a specialized one with the products it } \\
\text { sells. }\end{array}$ & .871 & $14.790 *$ & \multirow{2}{*}{.881} & \multirow{7}{*}{$\begin{array}{c}\text { Utilitarian } \\
\text { value, } \\
.917\end{array}$} \\
\hline & $\begin{array}{l}\text { When I think of this space, the first word that comes to me is } \\
\text { excellence. }\end{array}$ & .901 & $14.926 *$ & & \\
\hline \multirow{5}{*}{$\begin{array}{l}\text { Economic } \\
\text { value }\end{array}$} & Making my purchases in this space saves me time. & .846 & $14.552 *$ & \multirow{5}{*}{.920} & \\
\hline & $\begin{array}{l}\text { On the whole, I am satisfied with the costs of the products sold in } \\
\text { this space. }\end{array}$ & .888 & $14.450^{*}$ & & \\
\hline & $\begin{array}{l}\text { Making my purchases in this space is very convenient with my } \\
\text { schedule. }\end{array}$ & .877 & $15.219 *$ & & \\
\hline & Making my purchases in this space simplifies my life. & .787 & $11.667 *$ & & \\
\hline & The quality-price rapport of products sold in this space is excellent. & .763 & $11.577^{*}$ & & \\
\hline \multirow{3}{*}{ Satisfaction } & I am satisfied with my visit to this space. & .934 & $12.312^{*}$ & \multirow{3}{*}{.952} & \\
\hline & I think that I had a good idea when I decided to come to this space. & .917 & $11.808^{*}$ & & \\
\hline & I am happy to have been in this space. & .946 & $13.700 *$ & & \\
\hline \multirow{3}{*}{$\begin{array}{l}\text { Attitudinal } \\
\text { loyalty }\end{array}$} & I will come back in this space to buy a product identified today. & .895 & $20.190 *$ & \multirow{3}{*}{.950} & \\
\hline & I will recommend this space to my relatives. & .951 & $21.479 *$ & & \\
\hline & I will recommend products of this space to my relatives. & .944 & $22.677^{*}$ & & \\
\hline
\end{tabular}

* Coefficient significant at the 1\% level (Student $\mathrm{t}>|2.575|$ ). 
Table 4. Established links between first- and second-order factors of perceived value

\begin{tabular}{|l|c|c|}
\hline First-order factors $\leftarrow$ Second-order factors & Path coefficients & $t$ \\
\hline Aesthetics value $\leftarrow$ Hedonic value & .920 & $34.701^{*}$ \\
\hline Playfulness value $\leftarrow$ Hedonic value & .948 & $43.930^{*}$ \\
\hline Excellence value $\leftarrow$ Utilitarian value & .807 & $20.153^{*}$ \\
\hline Economic value $\leftarrow$ Utilitarian value & .967 & $55.807 *$ \\
\hline
\end{tabular}

* Coefficient significant at the $1 \%$ level (Student $t>|2.575|$ ). 
Table 5. Convergent and discriminant validity for perceived value

\begin{tabular}{|l|c|c|c|c|c|c|c|c|}
\hline & 1. & 2. & 3. & 4. & 5. & 6. & 7. & 8. \\
\hline 1. Hedonic value * & $\mathbf{0 . 8 7 3}$ & & & 0.509 & 0.463 & 0.414 & 0.380 & 0.281 \\
\hline 2. Aesthetics value & & $\mathbf{0 . 6 8 9}$ & 0.560 & 0.525 & 0.428 & 0.449 & 0.397 & 0.286 \\
\hline 3. Playfulness value & & 0.749 & $\mathbf{0 . 7 0 9}$ & 0.385 & 0.387 & 0.298 & 0.284 & 0.216 \\
\hline 4. Utilitarian value $*$ & 0.713 & 0.725 & 0.620 & $\mathbf{0 . 7 9 3}$ & & & 0.311 & 0.329 \\
\hline 5. Excellence value & 0.681 & 0.654 & 0.622 & & $\mathbf{0 . 7 8 6}$ & 0.397 & 0.231 & 0.183 \\
\hline 6. Economic value & 0.643 & 0.670 & 0.546 & & 0.630 & $\mathbf{0 . 6 9 5}$ & 0.277 & 0.325 \\
\hline 7. Satisfaction & 0.616 & 0.630 & 0.533 & 0.558 & 0.480 & 0.526 & $\mathbf{0 . 8 7 0}$ & 0.219 \\
\hline 8. Attitudinal loyalty & 0.530 & 0.535 & 0.464 & 0.573 & 0.427 & 0.570 & 0.468 & $\mathbf{0 . 8 6 6}$ \\
\hline
\end{tabular}

Notes: Average Variances Extracted (AVE) are shown in bold on the diagonal, the correlations are below the diagonal and the squared correlation appears above the diagonal.

* Second-order factor. 
Table 6. Inner model evaluation

\begin{tabular}{|c|c|c|c|c|}
\hline & $\beta$ & $t$ & $\mathrm{R}^{2}$ & $\begin{array}{c}\text { Adjusted } \\
\mathrm{R}^{2}\end{array}$ \\
\hline Hedonic value $\rightarrow$ Satisfaction & .460 & $6.170 *$ & \multirow{2}{*}{.414} & \multirow{2}{*}{.412} \\
\hline Utilitarian value $\rightarrow$ Satisfaction & .228 & $3.059 *$ & & \\
\hline Hedonic value $\rightarrow$ Attitudinal loyalty & .356 & $4.517^{*}$ & \multirow{3}{*}{.377} & \multirow{3}{*}{.372} \\
\hline Utilitarian value $\rightarrow$ Attitudinal loyalty & .186 & $2.227^{* *}$ & & \\
\hline Satisfaction $\rightarrow$ Attitudinal loyalty & .155 & $2.199 * *$ & & \\
\hline Hedonic value $\rightarrow$ Number of visits made & .229 & $2.537 * *$ & \multirow{4}{*}{.254} & \multirow{4}{*}{.244} \\
\hline Utilitarian value $\rightarrow$ Number of visits made & .206 & $2.224 * *$ & & \\
\hline Satisfaction $\rightarrow$ Number of visits made & .094 & n.s. & & \\
\hline Attitudinal loyalty $\rightarrow$ Number of visits made & .241 & $2.854 *$ & & \\
\hline Hedonic value $\rightarrow$ Total purchases made & .224 & $2.361^{* *}$ & \multirow{4}{*}{.220} & \multirow{4}{*}{.209} \\
\hline Utilitarian value $\rightarrow$ Total purchases made & .207 & $2.238 * *$ & & \\
\hline Satisfaction $\rightarrow$ Total purchases made & .095 & n.s. & & \\
\hline Attitudinal loyalty $\rightarrow$ Total purchases made & .176 & $2.302 * *$ & & \\
\hline
\end{tabular}

*Coefficient is significant at the $1 \%$ level (Student $t>|2.575|)$; ** Coefficient is significant at the $5 \%$ level (Student $t>|1.96|)$; n.s. Coefficient not significant. 
Table 7. Effects of individual and relational moderators

\begin{tabular}{|c|c|c|c|c|c|c|c|}
\hline & & & Women (n & 166) & & Men $(n=$ & \\
\hline & & $\beta$ & $t$ & $\mathrm{R}^{2} /$ Adj. $\mathrm{R}^{2}$ & $\beta$ & $t$ & $\mathrm{R}^{2} /$ Adj. $\mathrm{R}^{2}$ \\
\hline & Hedonic value $\rightarrow$ Satisfaction & .478 & $5.644^{*}$ & م72 & .127 & n.s. & $170+1 C 0$ \\
\hline & Utilitarian value $\rightarrow$ Satisfaction & .176 & $2.084^{* *}$ & $.3 / 4 / .3 / 0$ & .451 & $2.576^{*}$ & $.4 / 0 / .460$ \\
\hline & Hedonic value $\rightarrow$ Attitudinal loyalty & .341 & 4.096* & & .083 & n.s. & \\
\hline & Utilitarian value $\rightarrow$ Attitudinal loyalty & .216 & $2.398 * *$ & $.412 / .404$ & .407 & $2.970^{*}$ & $.272 / .243$ \\
\hline Impact of & Satisfaction $\boldsymbol{\rightarrow}$ Attitudinal loyalty & .188 & $2.470 * *$ & & .065 & n.s. & \\
\hline der & Hedonic value $\rightarrow$ Number of visits made & .240 & $2.086^{* *}$ & & .118 & n.s. & \\
\hline & Utilitarian value $\rightarrow \boldsymbol{\text { Number of visits made }}$ & .091 & n.s. & $239 / 225$ & .238 & $2.181^{* *}$ & $264 / 219$ \\
\hline & Satisfaction $\rightarrow$ Number of visits made & .114 & n.s. & (1) & 113 & n.s. & (2) \\
\hline & Attitudinal loyalty $\boldsymbol{\rightarrow}$ Number of visits made & .204 & $2.280 * *$ & & .117 & n.s. & \\
\hline & Hedonic value $\rightarrow$ Total purchases made & .235 & $2.207^{* *}$ & & 101 & n.s. & \\
\hline & Utilitarian value $\boldsymbol{\rightarrow}$ Total purchases made & .089 & n.s. & $209 / 194$ & .218 & $1.962 * *$ & $230 / 183$ \\
\hline & Satisfaction $\rightarrow$ Total purchases made & .112 & n.s & & .114 & n.s. & \\
\hline & Attitudinal loyalty $\rightarrow$ Total purchases made & .178 & $1.944 * * *$ & & .148 & n.s. & \\
\hline & & & $\begin{array}{r}x \text { hedonic } 0 \\
(n=116\end{array}$ & ientation ${ }^{1}$ & & $\begin{array}{r}\text { hedonic } \\
(\mathrm{n}=10 \\
\end{array}$ & ientation \\
\hline & & $\beta$ & $t$ & $\mathrm{R}^{2} / \operatorname{Adj} . \mathrm{R}^{2}$ & $\beta$ & $t$ & $\mathrm{R}^{2} /$ Adj. $\mathrm{R}^{2}$ \\
\hline & Hedonic value $\rightarrow$ Satisfaction & .354 & $2.342 * *$ & $165 / \Delta 61$ & .476 & $4.720^{*}$ & $310 / 212$ \\
\hline & Utilitarian value $\rightarrow$ Satisfaction & .283 & $2.943 *$ & (40J/.401. & .144 & n.s. & 3.54. \\
\hline & Hedonic value $\rightarrow$ Attitudinal loyalty & .273 & $2.566 * *$ & & 379 & $3.290^{*}$ & \\
\hline & Utilitarian value $\rightarrow$ Attitudinal loyalty & .284 & $2.830 *$ & $.398 / .387$ & .051 & n.s. & $.424 / .413$ \\
\hline $\begin{array}{l}\text { Impact of } \\
\text { motivational }\end{array}$ & Satisfaction $\rightarrow$ Attitudinal loyalty & .063 & n.s. & & .285 & $2.325^{* *}$ & \\
\hline orientations & Hedonic value $\rightarrow$ Number of visits made & .109 & n.s. & & .262 & $2.005^{* *}$ & \\
\hline & Utilitarian value $\rightarrow$ Number of visits made & .254 & $2.430 * *$ & $203 / 181$ & .104 & n.s. & $327 / 307$ \\
\hline & Satisfaction $\rightarrow$ Number of visits made & .082 & n.s. & (101.101 & .084 & n.s. & ו \\
\hline & Attitudinal loyalty $\rightarrow$ Number of visits made & .112 & n.s. & & .277 & $2.537 * *$ & \\
\hline & Hedonic value $\rightarrow$ Total purchases made & .077 & n.s. & & .356 & $2.715^{*}$ & \\
\hline & Utilitarian value $\boldsymbol{\rightarrow}$ Total purchases made & .346 & $2.509^{* *}$ & $100 / 177$ & .090 & n.s. & סכר | \\
\hline & Satisfaction $\rightarrow$ Total purchases made & .121 & n.s. & / & .118 & n.s. & 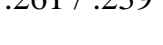 \\
\hline & Attitudinal loyalty $\boldsymbol{\rightarrow}$ Total purchases made & .147 & n.s. & & .273 & $2.537^{* *}$ & \\
\hline & & & $\begin{array}{l}\text { Weak assoc } \\
\text { th the store }\end{array}$ & $\begin{array}{l}\text { ation } \\
(n=74)\end{array}$ & & $\begin{array}{l}\text { evated ass } \\
\mathrm{h} \text { the store }\end{array}$ & $\begin{array}{l}\text { iation } \\
\mathrm{l}=145)\end{array}$ \\
\hline & & $\beta$ & $t$ & $\mathrm{R}^{2} / \operatorname{Adj} . \mathrm{R}^{2}$ & $\beta$ & $t$ & $\mathrm{R}^{2} /$ Adj. $\mathrm{R}^{2}$ \\
\hline $\begin{array}{l}\text { Impact of } \\
\text { relationship }\end{array}$ & Hedonic value $\rightarrow$ Satisfaction & .084 & n.s. & $415 / 406$ & .521 & $5.900^{*}$ & $406 / 402$ \\
\hline $\begin{array}{l}\text { relatuonsmip } \\
\text { age }\end{array}$ & Utilitarian value $\rightarrow$ Satisfaction & .370 & $2.678^{*}$ & $.415 / .406$ & .052 & n.s. & $.406 / .402$ \\
\hline & Hedonic value $\rightarrow$ Attitudinal loyalty & .043 & n.s. & & .218 & $2.074^{* *}$ & \\
\hline & Utilitarian value $\rightarrow$ Attitudinal loyalty & .395 & $2.720^{*}$ & $.419 / 403$ & .088 & n.s. & $.332 / .322$ \\
\hline & Satisfaction $\boldsymbol{\rightarrow}$ Attitudinal loyalty & .137 & n.s. & & .231 & $2.325^{* *}$ & \\
\hline
\end{tabular}

${ }^{1}$ Those with a median score between 3 and 8 (15 point scale grading) were categorized as having a weak hedonic orientation; respondents with a median score between 9 and 15 were categorized as having a strong hedonic orientation.

${ }^{2}$ Respondents who frequented the point of sale less than once a week were categorized as having a weak association with the store. Those who frequented the store one or more times per week were categorized as having a stronger association with the store. 


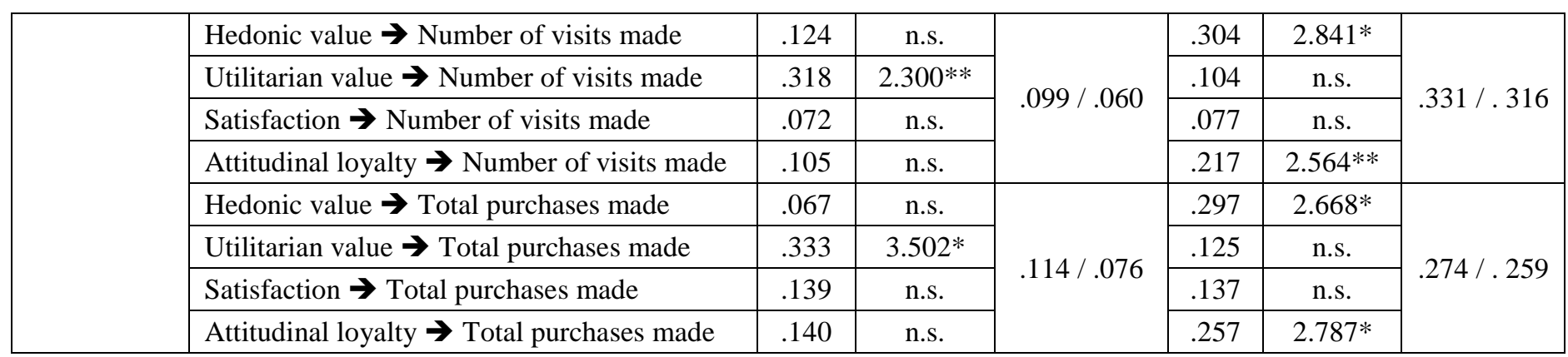

* Coefficient significant at the $1 \%$ level (Student $t>|2.575|)$. ${ }^{* *}$ Coefficient significant at the 5\% level (Student $t$ $>|1.96|)$. n.s. Coefficient not significant. 


\section{FIGURE}

Figure 1. Proposed model of perceived value / satisfaction - loyalty

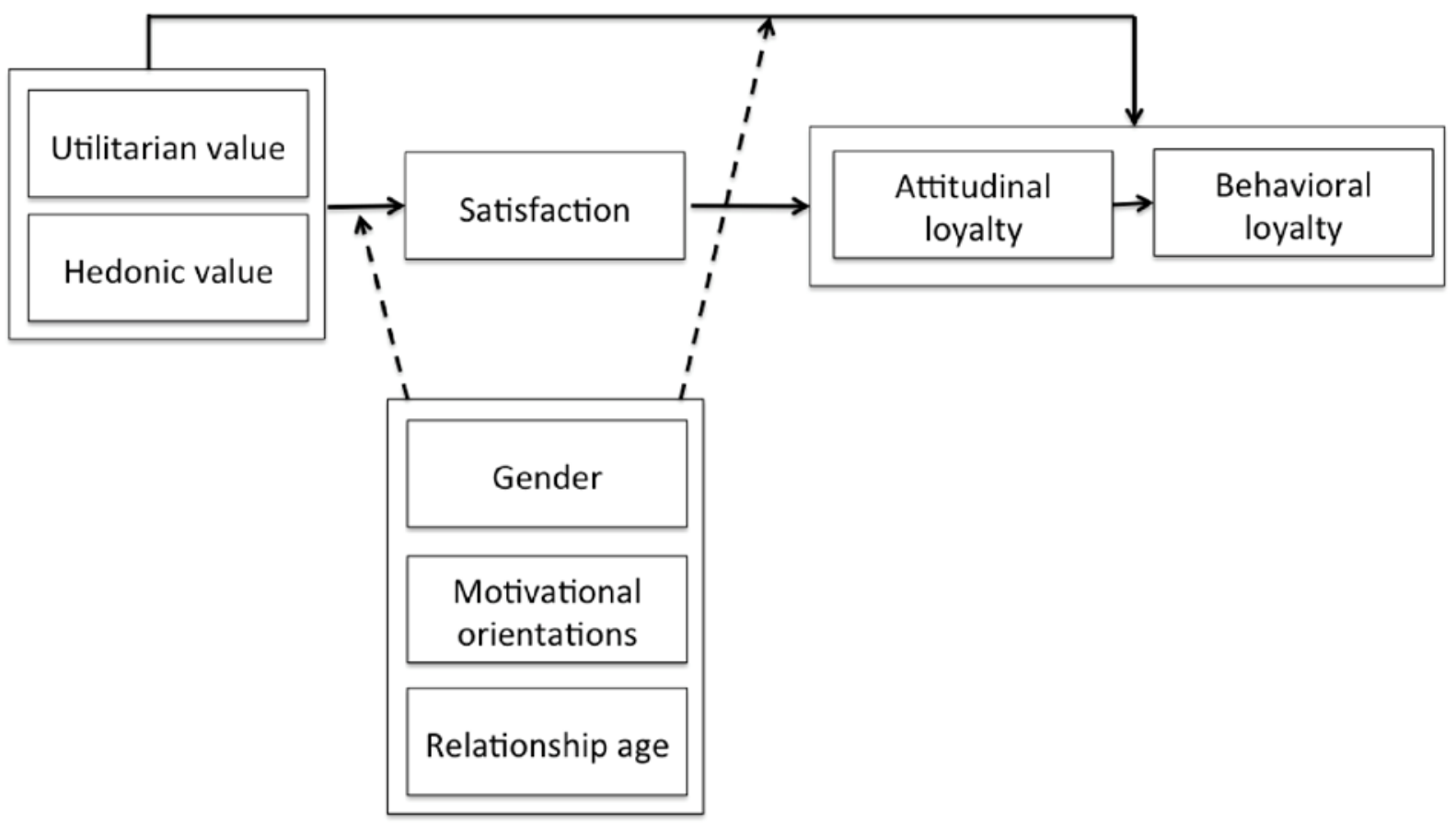

